\title{
UJI AKTIVITAS ANTIBAKTERI INFUSA AKAR BAYAM DURI (Amaranthus spino- sus L.) TERHADAP Shigella flexneri
}

\section{Farida Nuriyatun}

\begin{abstract}
ABSTRAK
$\mathrm{P}$ enelitian ini bertujuan untuk mengetahui aktivitas antibakteri infusa akar bayam duri (Amaranthus spinosus L) terhadap Shigella flexneri secara in vitro, untuk mengetahui infusa akar bayam duri (Amaranthus spinosus L) terhadap bakteri Shigella flexneri.

Penelitian ini menggunakan 5 perlakuan konsentrasi infusa akar bayam duri (Amaranthus spinosus L.) yaitu 50\%, 25\%, 12,5\%,6,25\%, dan 3,125\%. Pembuatan infusa dilakukan dengan metode infundasi, sedangkan uji antibakteri dilakukan dengan metode dilusi cair. KHM (Konsentrasi Hambat Minimum) ditentukan dengan pengamatan kekeruhan dan kejernihan dari masing-masing larutan uji dan dibandingkan dengan larutan kontrol, sedangkan KBM (Konsentrasi Bunuh Minimum) ditentukan dengan pengamatan ada tidaknya bakteri yang tumbuh pada media Mc Conkey . Data hasil penelitian dianalisis dengan analisis deskriptif.

Hasil penelitian menunjukkan bahwa KHM tidak dapat ditentukan karena infusanya keruh dan KBM juga tidak dapat ditentukan karena semua ruang pada cawan petri ditumbuhi bakteri, sehingga dapat disimpulkan bahwa infusa akar bayam duri (Amaranthus spinosus L) tidak memperlihatkan aktivitas antibakteri terhadap Shigella flexneri. Hasil penelitian ini diharapkan dapat dimanfaatkan sebagai alternatif sumber belajar biologi di SMA kelas X semester I untuk mencapai Kompetensi Dasar Mendeskripsikan Ciri-Ciri Archaeobacteria dan Eubacteria dan Peranannya dalam Kehidupan.
\end{abstract}

Kata kunci : antibakteri, infusa akar bayam duri (Amaranthus spinosus. L), Shigella flexneri. 


\section{PENDAHULUAN}

Penyakit infeksi yang disebabkan oleh bakteri atau virus merupakan salah satu penyakit yang sering terjadi di daerah Indonesia. Hal ini didukung oleh kenyataan bahwa Indonesia merupakan negara berkembang dengan jumlah penduduk golongan ekonomi menengah ke bawah cukup tinggi, juga cara hidup yang kurang sehat dan rendahnya tingkat pendidikan menyebabkan rendahnya kesadaran tentang pentingnya kesehatan. Dengan rendahnya kesadaran tersebut menyebabkan cepatnya penularan penyakit yang disebabkan oleh bakteri atau virus. Penyembuhan penyakit yang disebabkan oleh bakteri atau virus masih banyak menggunakan obat antibakteri dalam bentuk kimia sintetik. Penggunaan obat antibakteri kimia dapat menyebabkan timbulnya resistensi bakteri pada penggunaan yang tidak tepat. Kebanyakan masyarakat tidak mengetahui adanya bahaya (efek samping) yang ditimbulkan apabila menggunakan obat antibakteri kimiawi sintetik dengan tidak tepat, maka perhatian dunia sekarang berbalik pada cara pengobatan tradisional (Wijayakusuma, 1994).

Penggunaan tumbuhan obat sebagai obat tradisional dipercaya cukup efektif dan aman karena jarang menimbulkan efek samping dan harganya relatif murah. Obat tradisional dapat diperoleh dari biji, daging buah, daun, kulit, batang, bunga, maupun akar suatu tumbuhan yang mengandung zat kimia yang memiliki pengaruh dalam pengobatan penyakit. Usaha pemanfaatan tumbuhan obat pada hakekatnya adalah memberi pengetahuan kepada masyarakat tentang macam-macam tumbuhan yang berguna sebagai obat tradisional sehingga masyarakat dapat menolong dirinya sendiri dalam bidang kesehatan.

Salah satu tanaman yang digunakan sebagai obat tradisional adalah Amaranthus spinosus L. atau yang lebih dikenal dengan bayam duri. Tumbuhan ini digunakan sebagai diuretika yang biasanya direbus atau diperas lalu diminum. Bayam duri digunakan sebagai obat karena mengandung beberapa zat kimia yang memiliki efek farmakologis seperti tanin dan flavonoid (Wijayakusuma, 1994). Tanin dan flavonoid merupakan senyawa fenol yang bersifat polar. Senyawa polar akan larut dalam pelarut polar. Senyawa polar yang biasa digunakan untuk menyari glikosida flavonoid adalah air, metanol, etanol, butanol, aseton, dimetilsuloksida, dan dimetil formamid (Sardjoko, 1989).Tanin dan flavonoid dapat berfungsi sebagai antimikrobia dan antivirus (Robinson, 1995). Salah satu mikrobia yang menyebabkan penyakit adalah Shigella flexneri. Shigella flexneri termasuk bakteri gram negatif yang

menyebabkan penyakit disentri (Volk 
dan Wheeler, 1990).

Disentri adalah peradangan usus, diare buang air besar yang berair dan bercampur darah, lendir dan nanah. Pada disentri seringkali disertai muntah-muntah sehingga tubuh kehilangan air dan garam-garamnya, keadaan ini sering disebut dehidrasi (Pelczar dan Chan, 1988).

Berdasarkan uraian tersebut penting kiranya dilakukan penelitian tentang uji aktivitas antibakteri infusa akar bayam duri (Amaranthus spinosus L.) terhadap bakteri Shigella flexneri. Penelitian ini penting untuk dilakukan karena bakteri dapat mengalami resistensi sehingga diperlukan obat baru yang lebih efektif dan murah.

Dalam penelitian ini digunakan infusa karena kandungan zat kimia dalam akar bayam duri (Amaranthus spinosus. L) yaitu tanin dan flavonoid bersifat polar yang dapat larut dalam air. Selain itu masyarakat biasa menggunakan obat tradisional dengan cara merebusnya dengan air saja. Hasil penelitian ini diharapkan dapat digunakan sebagai alternatif sumber belajar biologi di SMA kelas X untuk mencapai kompetensi dasar mendeskripsikan ciri-ciri Archaebacteria dan Eubacteria dan peranannya dalam kehidupan.

\section{METODE PENELITIAN}

Sampel yang digunakan dalam penelitian ini adalah infusa akar bayam duri ( $\mathrm{Am}$ - aranthus spinosus L.) dengan konsentrasi $50 \%, 25 \%, 12,5 \%, 6,25 \%, 3,125 \%$. Bakteri yang digunakan adalah Shigella flexneri.

Metode penelitian yang dilakukan adalah:

\section{Identifikasi tanaman bayam duri (Amaranthus spinosus L.)}

Dilakukan di Laboratorium Biologi Farmasi Fakultas Farmasi Universitas Gadjah Mada Yogyakarta dengan menggunakan buku Flora of Java (Spermathophytes only) Vol 1 karangan Becker CA dan Bagu Khuisen van den Bring (1962).

\section{Pembuatan simplisia dan infusa akar bayam duri (Amaranthus spi- nosus $L$ ).}

Akar bayam duri (Amaranthus spinosus L) sebanyak $1 \mathrm{~kg}$ dibersihkan dan dicuci dengan air mengalir sampai bersih, dan dirajang. Setelah itu dikeringkan di bawah sinar matahari langsung dengan cara ditutupi kain hitam, yang bertujuan untuk melindungi bahan terhadap pengaruh sinar ultra violet dari matahari.

Setelah kering akar bayam duri diblender sehingga menjadi serbuk. Infusa akar bayam duri 100\% dibuat dengan menimbang $100 \mathrm{~g}$ serbuk akar bayam duri kemudian ditambahkan dengan air $100 \mathrm{ml}$, dan ditambahkan air ekstra 2 kali jumlah simplisia

Kemudian dipanaskan dalam penangas air selama 15 menit, dihitung mulai 
suhu di dalam panci mencapai $90^{\circ} \mathrm{C}$ sambil sekali-kali diaduk. Infusa diseka dengan kain flanel kemudian ditambahkan air mendidih melalui ampasnya sehingga diperoleh volume $100 \mathrm{ml}$ (Anonim, 1986).

\section{Sterilisasi}

Semua alat dicuci bersih dan dikeringkan, alat-alat seperti cawan petri, pipet ukur dibungkus dengan kertas koran, sedangkan tabung reaksi disumbat dengan kapas dengan metode panas kering. Kemudian disterilkan dengan oven pada suhu $170^{\circ} \mathrm{C}$ $180^{\circ} \mathrm{C}$ selama 2 jam. Bahan-bahan disterilkan dengan autoklaf pada suhu $121^{\circ} \mathrm{C}$, tekanan $1 \mathrm{~atm}$ selama 15 menit (Anonim, 1993).

\section{Pembuatan suspensi Shigella flexne- ri}

Diambil satu ose dari biakan Shigella flexneri dimasukkan ke dalam $2 \mathrm{ml}$ media BHI (Brain Heart Infusion), kemudian diinkubasi pada suhu $37^{\circ} \mathrm{C}$ selama 24 jam. Kemudian hasil dari inkubasi diambil 200 $\mu \mathrm{l}$ dimasukkan ke dalam $2 \mathrm{ml}$ media BHI, kemudian diinkubasi pada suhu $37^{\circ} \mathrm{C}$ selama 4-8 jam. Diencerkan sedikit demi sedikit dengan larutan $\mathrm{NaCl}$ 0,9\% steril hingga kekeruhan sesuai dengan standar Mc Farland (konsentrasi bakteri 108CFU/ml ). Dari suspensi bakteri yang memiliki angka kekeruhan $108 \mathrm{CFU} / \mathrm{ml}$, kemudian diambil $100 \mu \mathrm{l}$ suspensi dimasukkan ke dalam 10ml BHI DS sehingga diperoleh angka kuman 106
$\mathrm{CFU} / \mathrm{ml}$.

\section{Pembuatan larutan sampel.}

Disiapkan infusa akar bayam duri (Amaranthus spinosus L.) dengan konsentrasi $100 \%$. Disiapkan 9 tabung reaksi, tabung reaksi satu sampai dengan delapan diberi tanda 1 sampai 5 dan tabung yang lain K (1) kontrol media BHI DS , K (II) kontrol suspensi bakteri, K(III) kontrol infusa akar bayam duri (Amaranthus spinosus L.), K (VI) kontrol pelarut (aquadest steril). Tabung no 2 sampai 5 ditambah masing-masing $1 \mathrm{ml}$ aquadest steril. Tabung no 1 diisi dengan 2 $\mathrm{ml}$ infusa akar bayam duri (Amaranthus spinosus L.) konsentrasi 100\% sehingga konsentrasi pada tabung 1 adalah 100\%. Diambil $1 \mathrm{ml}$ dari tabung 1, dimasukkan ke dalam tabung 2 sehingga konsentrasi infusa pada tabung 2 adalah 50\%, kemudian divortek. Dari tabung 2 diambil $1 \mathrm{ml}$, dimasukkan ke dalam tabung 3 sehingga konsentrasi infusa pada tabung 3 adalah setengah dari konsentrasi tabung 2 (sebelumnya). Begitu seterusnya sampai tabung 5. Sisa pengenceran dari tabung 8 dibuang (Anonim, 1979). Dari tabung reaksi no 1 sampai 5 masing-masing ditambahkan $1 \mathrm{ml}$ suspensi bakteri ( 106 $\mathrm{CFU} / \mathrm{ml}$ ), sehingga jika pada masing-masing konsentrasi tersebut ditambah suspensi bakteri dengan perbandingan volume $1 \mathrm{ml}: 1$ ml, maka konsentrasi akhir infusa menjadi $50 \%, 25 \%, 12,5 \%, 6,3 \%, 3,1 \%$ kemudian 
dilakukan pemvortekan mulai dari tabung 1 sampai tabung 5 .

Sesudah terjadi pengenceran diinkubasi ke dalam inkubator selama 24 jam pada suhu $37 \mathrm{oC}$.

\section{Uji Antibakteri}

a. Ditentukan KHM (Konsentrasi Hambat Minimum)nya, KHM ditentukan dengan pengamatan kekeruhan dan kejernihan dari masing-masing larutan uji dan dibandingkan dengan larutan kontrol media. Konsentrasi paling rendah yang memperlihatkan penghambatan pertumbuhan bakteri ditandai dengan jernihnya larutan uji merupakan KHM (Kuswandi dkk, 2000).

$\mathrm{K}=$ keruh

$\mathrm{J}=$ jernih

b. Diambil 1 ose bakteri dari masing-masing tabung uji kemudian digoreskan pada media agar Mc Conkey, diinkubasi pada suhu 370C selama 24 jam.

c. Ditentukan KBM (Konsentrasi Bunuh Minimum)-nya, KBM ditentukan dengan pengamatan ada tidaknya bakteri yang tumbuh pada media Mc Conkey, Konsentrasi terendah yang memperlihatkan kematian bakteri ditandai dengan tidak adanya bakteri yang tumbuh pada media Mc Conkey tersebut merupakan KBM (Kuswandi dkk, 2000).

$+=$ tidak ada bakteri yang tumbuh - = ada bakteri yang tumbuh

\section{HASIL DAN PEMBAHASAN}

\section{Identifikasi Tanaman}

Identifikasi tanaman perlu dilakukan untuk memastikan bahwa tanaman yang digunakan dalam penelitian benar-benar tanaman bayam duri (Amaranthus spinosus L) sehingga tidak terjadi kekeliruan dengan tanaman lain yang mirip. Identifikasi di lakukan dengan mengamati ciri-ciri morfologi tanaman.

Ciri-ciri morfologi tanaman bayam duri yang digunakan dalam penelitian ini batang berwarna kemerahan, bagian pangkal polos, bagian atas sedikit berambut. Daun tunggal tumbuh berseling, warnanya kehijauan, bentuknya bundar telur memanjang sampai lanset, ujung daun tumpul dan pangkalnya runcing, diketiak daun terdapat sepasang duri keras. Ciri-ciri morfologi tanaman tersebut menunjukkan bahwa tanaman yang digunakan dalam penelitian ini adalah bayam duri (Amaranthus spinosus L).

Identifikasi tanaman dilakukan di laboratorium Farmasi Universitas Gadjah Mada. Hasil identifikasi tanaman di atas menunjukkan bahwa tanaman yang digunakan dalam penelitian ini adalah tanaman bayam duri (Amaranthus spinosus L.). Bukti identifikasi terhadap tanaman bayam duri (Amaranthus spinosus L.) terdapat pada surat keterangan determinasi yang terlampir pada lampiran 3 . 


\section{Hasil Penyarian Simplisia}

Pembuatan simplisia akar bayam duri ditutup dengan kain hitam untuk mencegah kerusakan bahan kimia dalam tanaman. Selain itu kain hitam dapat menyerap panas lebih banyak sehingga dapat mempercepat proses pengeringan. Manfaat pengeringan adalah untuk mengurangi kandungan air sehingga mencegah terjadinya pembusukan, tumbuh jamur dan untuk menghentikan terjadinya reaksi enzimatis di dalam sel, kerja bakteri serta perubahan kimia.

Apabila kadar air tinggi maka dapat menyebabkan terjadinya proses hidrolisis dan oksidasi, yang akan mempengaruhi kandungan aktif bahan tersebut. Tujuan pengeringan adalah untuk mendapatkan simplisia yang tidak mudah rusak sehingga dapat disimpan dalam waktu lama (Anonim, 1985).

Akar yang sudah kering diserbuk dengan menggunakan blender. Dengan demikian ukuran partikel menjadi lebih kecil sehingga penyarian akan berlangsung secara efektif. Sebab semakin kecil ukuran partikel serbuk maka semakin luas permukaannya dan kontak antara serbuk dengan cairan penyari akan lebih baik. Tetapi kecilnya ukuran serbuk tidak sampai merusak sel dalam akar bayam duri tersebut.

Setelah menjadi serbuk kemudian dibuat infusa. Dalam penelitian ini digunakan infusa karena kandungan zat kimia dalam akar bayam duri (Amaranthus spinosus L.) yaitu tanin dan flavonoid bersifat polar yang dapat larut dalam air (Sardjoko, 1989).

\section{Hasil Uji Bakteri}

Pada pengujian aktivitas antibakteri semua alat dan bahan yang digunakan harus disterilisasi terlebih dahulu, untuk mencegah kontaminasi. Adanya kontaminasi akan mempersulit dalam proses penentuan hasil akhir. Pada pengujian aktifitas antibakteri dilakukan dengan metode dilusi cair. Metode ini digunakan karena, homogenitas antar media dalam bahan uji dan kuman lebih terjamin sehingga interaksi ketiganya lebih sempurna. Media dan bahan uji digunakan juga lebih sedikit sehingga menghemat media dan bahan uji. Kegunaan dari metode dilusi ini adalah untuk mencari Kadar Hambat Minimum (KHM) yaitu kadar obat terendah yang menghambat pertumbuhan bakteri (Anonim,1993).

Pengujian antibakteri dilakukan sebanyak 5 kali perlakuan yaitu pada konsentrasi $50 \%, 25 \%, 12.5 \%, 6.3 \%$, dan $3.1 \%$ dengan 5 kali ulangan. Hasil uji penentuan KHM infusa akar bayam duri (Amarantus spinosus L.) dapat dilihat pada Gambar 6 dan Tabel 1 berikut: 


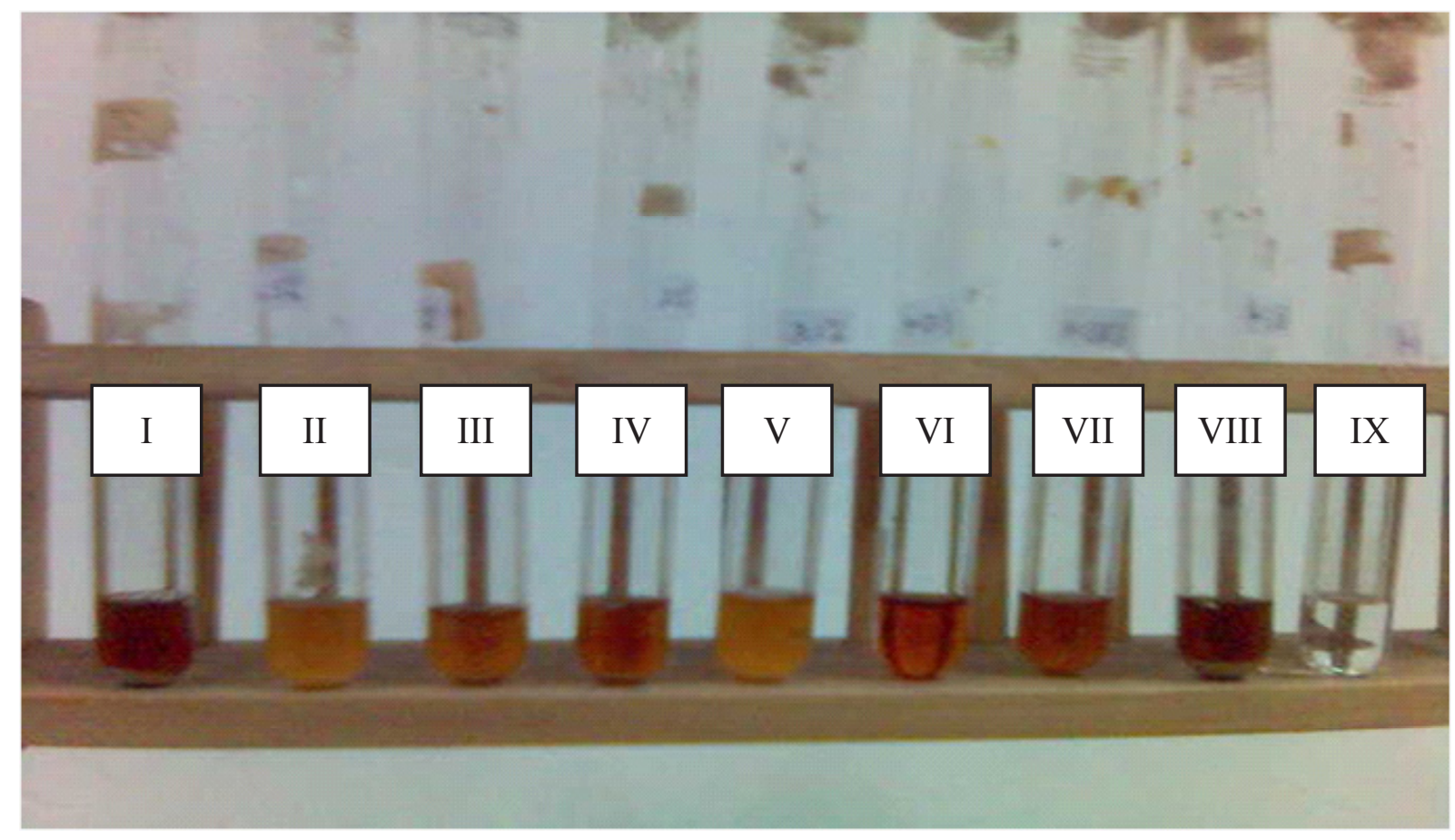

Gambar 6. Foto Hasil KHM Infusa Akar Bayam Duri (Amaranthus spinosus L) terhadap Shigella flexneri

\section{Keterangan:}

Tabung I : infusa akar bayam duri dengan konsentrasi akhir 50\% b/v

Tabung II : infusa akar bayam duri dengan konsentrasi akhir $25 \% \mathrm{~b} / \mathrm{v}$

Tabung III : infusa akar bayam duri dengan konsentrasi akhir 12,5\% b/v

Tabung IV : infusa akar bayam duri dengan konsentrasi akhir $6,3 \% \mathrm{~b} / \mathrm{v}$

Tabung $\mathrm{V} \quad$ : infusa akar bayam duri dengan konsentrasi akhir 3,1\% b/v

K I : kontrol BHI DS

K II : kontrol Suspensi bakteri (Shigella flexneri)

K III : kontrol infusa (akar bayam duri)

K IV : kontrol aquades

\begin{tabular}{|c|c|c|}
\hline No & $\begin{array}{c}\text { Konsentrasi akhhir infusa } \\
\text { akar bayam duri (Amaran- } \\
\text { tus spinosus L) }\end{array}$ & KHM \\
\hline 1 & $50 \%$ & $\mathrm{~K}$ \\
\hline 2 & $25 \%$ & $\mathrm{~K}$ \\
\hline 3 & $12.5 \%$ & $\mathrm{~K}$ \\
\hline 4 & $6.3 \%$ & $\mathrm{~K}$ \\
\hline 5 & $3.1 \%$ & $\mathrm{~K}$ \\
\hline 6 & $\mathrm{~K}(\mathrm{I})$ & $\mathrm{J}$ \\
\hline 7 & $\mathrm{~K}(\mathrm{II})$ & $\mathrm{K}$ \\
\hline 8 & $\mathrm{~K}(\mathrm{III})$ & $\mathrm{K}$ \\
\hline 9 & $\mathrm{~K}(\mathrm{IV})$ & $\mathrm{J}$ \\
\hline
\end{tabular}

1Tabel 1. Hasil uji penentuan KHM infusa akar bayam duri (Amarantus spinosus $L$.) terhadap Shigella flexneri.

Keterangan:

K : keruh

J : jernih

K(I ) : kontrol BHI DS

K(II) : kontrol suspensi bakteri

K(III) : kontrol infusa

K(IV) : kontrol aquades

Berdasarkan Gambar 6 dan Tabel 1 dapat dilihat bahwa pada pengujian KHM semua tabung keruh sehingga nilai KHM sulit ditentukan, untuk itu perlu dilakukan penggoresan di dalam media Mc Conkey 2013 HAL. 1 - 96 
untuk menguji nilai KBM-nya. Hasil pengujian KBM dapat dilihat pada Gambar 7 dan Tabel 2 berikut ini:

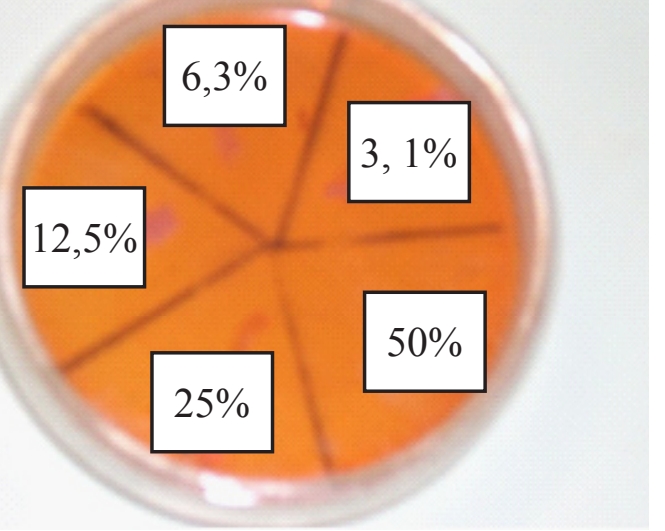

Gambar 7. Foto Hasil Uji Penentuan KBM Infusa Akar Bayam Duri (Amaranthus spinosus $L$ )

Keterangan:

Ruang I : infusa akar bayam duri dengan konsentrasi akhir $50 \% \mathrm{~b} / \mathrm{v}$

Ruang II : infusa akar bayam duri dengan konsentrasi akhir $25 \% \mathrm{~b} / \mathrm{v}$

Ruang III : infusa akar bayam duri dengan konsentrasi akhir $12,5 \% \mathrm{~b} / \mathrm{v}$

Ruang IV : infusa akar bayam duri dengan konsentrasi akhir $6,3 \% \mathrm{~b} / \mathrm{v}$

Ruang $\mathrm{V}$ : infusa akar bayam duri dengan konsentrasi akhir 3,1\% b/v

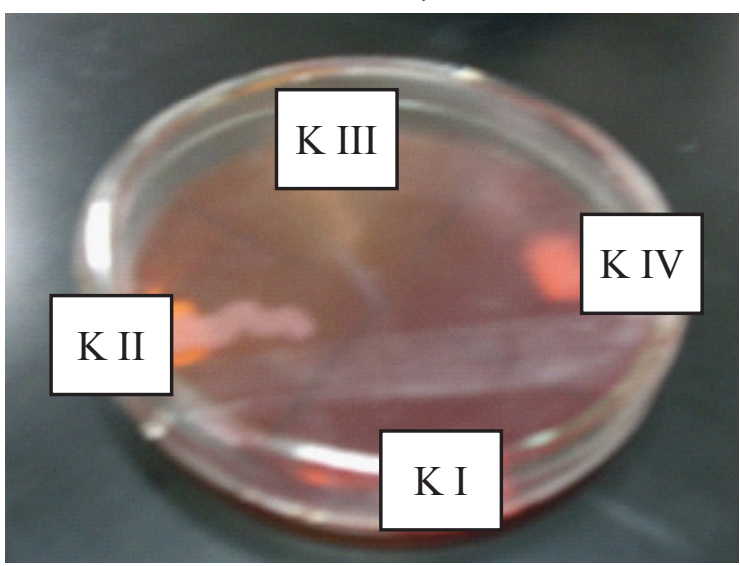

Gambar 8. Foto Hasil Uji Kontrol Dalam Penentuan KBM Infusa Akar Bayam Duri (Amaranthus spinosus L.)
Keterangan:

K I : kontrol BHI DS

K II : kontrol Suspensi bakteri (Shigella flexneri)

K III : kontrol infusa (akar bayam duri)

K IV : kontrol aquades

\begin{tabular}{|c|c|c|}
\hline No & $\begin{array}{c}\text { Konsentrasi akhhir infusa } \\
\text { akar bayam duri (Amaran- } \\
\text { tus spinosus L) }\end{array}$ & KBM \\
\hline 1 & $50 \%$ & - \\
\hline 2 & $25 \%$ & - \\
\hline 3 & $12.5 \%$ & - \\
\hline 4 & $6.3 \%$ & - \\
\hline 5 & $3.1 \%$ & - \\
\hline 6 & $\mathrm{~K}(\mathrm{I})$ & + \\
\hline 7 & $\mathrm{~K}(\mathrm{II})$ & - \\
\hline 8 & $\mathrm{~K}(\mathrm{III})$ & + \\
\hline 9 & $\mathrm{~K}(\mathrm{IV})$ & + \\
\hline
\end{tabular}

Keterangan:

(+) : bakteri tidak tumbuh

(-) : bakteri tumbuh

K I : kontrol BHI DS

K II : kontrol Suspensi bakteri (Shigella flexneri)

K III : kontrol infusa (akar bayam duri)

K IV : kontrol aquades

\section{Pembahasan}

Dalam pengujian antibakteri konsentrasi akhir infusa akar bayam duri (Amaranthus spinosus $L$ ) adalah 50\%, 25\%, 12.5\%, $6.3 \%$, dan 3.1\%. Dalam penelitian ini diperlukan beberapa larutan kontrol yang berfungsi sebagai pembanding maupun untuk mengetahui sterilitas dari bahan yang dipakai. 
Penelitian ini menggunakan 4 kontrol yaitu kontrol BHI DS, kontrol suspensi bakteri, kontrol infusa dan kontrol aquades. Dari hasil uji KHM dengan mengamati tingkat kekeruhan dan kejernihan dari masing-masing larutan uji setelah dibandingkan dengan larutan kontrol media di dapat bahwa semua tabung keruh kecuali pada tabung kontrol BHI DS dan kontrol aquades. Kekeruhan pada kontrol infusa dapat disebabkan karena infusa akar bayam duri tersebut keruh atau mungkin karena adanya pertumbuhan bakteri. Oleh karena itu dilakukan pembuktian dengan menggoreskan kontrol infusa pada media Mc Conkey. Hasil penggoresan tersebut didapatkan bahwa tidak ada mikroorganisme yang tumbuh. Hal itu membuktikan bahwa kontrol infusa akar bayam duri (Amaranthus spinosus L) bersifat steril.

Pada tabung larutan uji didapat semua tabung keruh sehingga KHM tidak dapat ditentukan. Kekeruhan pada larutan uji belum dapat menunjukkan bahwa infusa akar bayam duri tidak dapat menghambat pertumbuhan bakteri Shigella flexneri. Kekeruhan pada larutan uji belum tentu disebabkan oleh adanya bakteri yang tumbuh tetapi dapat disebabkan karena infusa akar bayam duri tersebut keruh atau mungkin karena adanya pertumbuhan bakteri, seperti kekeruhan pada kontrol infusa. Oleh karena itu, perlu dilanjutkan dengan uji KBM yaitu dengan menggoreskan 1 ose dari masing-masing larutan uji ke dalam media Mc. Conkey.

Berdasarkan Gambar 8 dapat dilihat bahwa kontrol suspensi ditumbuhi bakteri, kontrol BHI DS, kontrol aquades dan kontrol infusa tidak ditumbuhi bakteri, sehingga dapat dinyatakan semua bahan dan media uji bersifat steril. Sedangkan pada Gambar 7 semua larutan uji infusa akar bayam duri dengan konsentrasi $(50 \%, 25 \%, 12,5 \%$, $6,3 \%, 3,1 \%$ ) tampak ditumbuhi bakteri. Hal ini dapat menandakan bahwa infusa akar bayam duri (Amaranthus spinosus. L) tidak dapat membunuh bakteri Shigella flexneri, tetapi berdasarkan hasil penelitian Feteriyani (2004) tentang uji aktivitas antibakteri infusa akar bayam duri (Amaranthus spinosus. L) terhadap Staphylococcus aureus ATCC 25923 dan Escherichia coli ATCC 35218 dihasilkan bahwa hasil uji KHM infusa akar bayam duri untuk Staphylococcus aureus ATCC 25923 adalah 22,5\%b/v dan KBM-nya adalah $25 \% \mathrm{~b} / \mathrm{v}$ sedangkan untuk Escherichia coli ATCC 35218 didapatkan nilai KHM-nya sebesar 20\%b/v dan KBMnya sebesar 22,5\%b/v. Hal tersebut membuktikan bahwa infusa akar bayam duri (Amaranthus spinosus. L) dapat membunuh bakteri Staphylococcus aureus ATCC 25923 dan Escherichia coli ATCC 35218.

Penyebab infusa akar bayam duri ( $\mathrm{Am}$ aranthus spinosus. $L$ ) dapat membunuh bakteri Staphylococcus aureus ATCC 25923 dan Escherichia coli ATCC 35218 adalah senya- 
wa yang terkandung dalam akar bayam duri.

Beberapa senyawa yang terkandung dalam akar bayam duri adalah tanin dan flavonoid (Wijayakusuma, 1994).

Tanin adalah suatu kelompok dari unsur polimer fenol yang berfungsi sebagai astringen. Tanin mampu mengganggu sintesis dinding sel, yaitu dengan cara bereaksi dengan protein dan bekerja mengendapkan protein. Apabila terjadi pengendapan protein maka pertumbuhan bakteri akan terganggu (Volk dan Margareth, 1993).

Menurut Robinson (1995) flavonoid dapat menginaktifkan DNA polimerase. Jika DNA polimerase tidak aktif maka sintesis protein akan dihambat. Flavonoid juga dapat merusak membran sel sehingga terjadi perubahan permeabilitas sel yang akan mengakibatkan terhambatnya pertumbuhan sel atau matinya sel (Pelezar dan Chan, 1988).

Sebenarnya tanin dan flavonoid bersifat antibakteri, walaupun dalam kenyataannya hasil penelitian ini menunjukkan bahwa infusa akar bayam duri (Amaranthus spinosus L.) dengan konsentrasi 50\% ke bawah tidak dapat membunuh bakteri Shigella flexneri. Hal tersebut dapat disebabkan oleh banyak faktor antara lain kadar senyawa aktif dalam simplisia akar bayam duri, infusa akar bayam duri dan struktur lipopolisakarida pada dinding sel bakteri.

Kadar senyawa aktif dalam suatu simplisia berbeda-beda. Faktor-faktor yang mempengaruhi kadar senyawa aktif dalam simplisia yaitu bagian tanaman yang digunakan, umur tanaman, waktu panen dan lingkungan tempat tumbuh. Perbedaan tempat tumbuh tanaman bayam duri (Amaranthus spinosus L.) ini menyebabkan perbedaan kandungan zat aktifnya. Pertumbuhan tanaman dipengaruhi oleh ketinggian tempat tumbuh, keadaan tanah dan cuaca (Anonim, 1985). Hal tersebut menyebabkan perbedaan kandungan zat aktif dalam simplisia akar bayam duri tersebut.

Pengambilan zat aktif dalam suatu tanaman dilakukan dengan proses penyarian. Jenis metode penyarian juga berpengaruh terhadap jumlah zat aktif yang tersaring. Penyarian dalam penelitian ini dalam bentuk infusa yaitu menyari simplisia nabati dengan air pada suhu $90^{\circ} \mathrm{C}$ selama 15 menit. Ada kemungkinan bahwa dengan metode penyarian infusa ini, senyawa yang bersifat antibakterial (khususnya terhadap bakteri Shigella flexneri) yang terkandung dalam tanaman akar bayam duri tidak dapat tersaring secara sempurna. Hal itu menyebabkan infusa akar bayam duri tidak dapat membunuh bakteri Shigella flexneri.

Selain itu struktur bakteri Shigella flexneri juga berpengaruh terhadap kekebalan bakteri Shigella flexneri terhadap zat antibakteri. Salah satunya yaitu lipopolisakarida. Lipopolisakarida (LPS) atau lebih dikenal dengan nama endotoksin. Endotoksin adalah 
suatu senyawa kompleks yang terdapat pada dinding sel bakteri gram negatif.

Lipopolysaccaride (LPS) adalah suatu komponen yang utama dari amplop Gramnegatif. Lipopolisakarida pada bakteri Shigella flexneri berperan untuk patogenesis. LPS terdiri dari dua bagian utama, yaitu bagian polisakarida dan bagian lipid. Bagian polisakarida merupakan rangkaian dari berbagai macam gula, yang dibagi lagi menjadi 3 segmen, yaitu segmen pertama berupa rantai O-spesifik (dibentuk oleh sedikitnya 3 rangkaian gula yang berulang). Segmen ini merupakan segmen yang sangat bervariasi dan memberikan efek kekebalan yang spesifik (Winarno, 1995).

Selain struktur bakteri resistensi bakteri terhadap zat antibakteri juga berpengaruh terhadap perbedaan bakteri Shigella flexneri dan bakteri Escherichia coli. Menurut Triadmojo (1996), bakteri Shigella flexneri lebih resisten daripada bakteri Escherichia coli. Hal tersebut yang menyebabkan bakteri Escherichia coli dapat dibunuh dengan infusa akar bayam duri sedangkan bakteri Shigella flexneri tidak dapat dibunuh dengan infusa akar bayam duri.

Implementasi Hasil Penelitian dalam Pembelajaran Biologi di SMA.

Hasil penelitian uji aktivitas antibakteri infusa akar bayam duri (Amaranthus spinosus L.) terhadap Shigella flexneri ini diharapkan dapat dimanfaatkan sebagai al- ternatif sumber belajar biologi di SMA kelas X untuk mencapai kompetensi dasar mendiskripsikan ciri-ciri archaebacteria dan eubacteria dan peranannya dalam kehidupan. Pemanfaatan hasil penelitian sebagai sumber belajar diwujudkan dalam bentuk modul pembelajaran. Tujuan pengalaman belajar dengan menggunakan modul adalah untuk membantu peserta didik mencapai tujuan pembelajaran yang lebih efektif dan efisien, serta memungkinkan peserta didik untuk melakukan pembelajaran secara aktif, tidak sekedar membaca dan mendengar, sehingga siswa dapat mencapai kompetensi dasar yang sesuai dengan Kurikulum Tingkat Satuan Pendidikan (KTSP).

Guru menentukan metode yang akan digunakan dalam melaksanakan kegiatan belajar mengajar. Metode yang digunakan dalam pembelajaran ini adalah ceramah, tanya jawab, dan diskusi.

Hasil penelitian uji aktivitas antibakteri infusa akar bayam duri (Amaranthus spinosus L.) terhadap Shigella flexneri sebagai alternatif sumber belajar akan disampaikan dalam 2 kali pertemuan. Adapun Langkahlangkah pembelajaran ini adalah sebagai berikut:

\section{Pendahuluan}

Pada pertemuan pertama guru membuka pelajaran dengan memberikan pertanyaan awal tentang bakteri secara umum. Kemudian pada pertemuan kedua guru mengingatkan 
kembali tugas mempelajari modul pembelajaran Archaeobacteria dan Eubacteria yang diberikan pada pertemuan sebelumnya.

\section{Kegiatan Inti}

Pada pertemuan pertama, dengan metode ceramah dan tanya jawab guru menjelaskan tentang ciri-ciri archaeobacteria dan eubacteria, perbedaan archaeobacteria dan eubacteria, contoh-contoh archaeobacteria dan eubacteria, penggolongan bakteri, perkembangbiakkan bakteri, peranan bakteri dalam kehidupan dan cara pengendalian bakteri patogen khususnya pada bakteri Shigella flexneri. Pada pertemuan kedua guru membagi siswa menjadi 8 kelompok diskusi, tiap kelompok berisi 5 siswa. Siswa melakukan diskusi tentang peranan bakteri Shigella flexneri dalam kehidupan dan cara pengendalian bakteri Shigella flexneri, kemudian dilanjutkan dengan mengerjakan lembar kerja siswa yang ada di dalam modul.

\section{Penutup}

Guru mengakhiri kegiatan pembelajaran pada pertemuan pertama dengan membuat kesimpulan tentang ciri-ciri archaeobacteria dan eubacteria, perbedaan archaeobacteria dan eubacteria, contoh archaeobacteria dan eubacteria penggolongan bakteri, penggolongan bakteri, perkembangbiakkan bakteri, peranan bakteri dalam kehidupan, dan cara pengendalian bakteri patogen khususnya pada bakteri Shigella flexneri; dan memberi tugas kepada siswa untuk mempelajari modul pembelajaran archaeobacteria dan eubacteria di rumah. Pada pertemuan kedua guru mengakhiri kegiatan pembelajaran dengan membuat kesimpulan hasil diskusi tentang tentang peranan bakteri Shigella flexneri dalam kehidupan dan cara pengendalian bakteri Shigella flexneri.

Di dalam proses pembelajaran harus disesuikan dengan kurikulum. Dalam pelaksanaan penyusunan kurikulum terdapat pengembangan silabus dan Rencana Pelaksanaan Pembelajaran (RPP). Berikut ini adalah pengembangan silabus dan Rencana Pelaksanaan Pembelajaran (RPP).

\section{KESIMPULAN}

Berdasarkan penelitian uji aktivitas antibakteri infusa akar bayam duri (Amaranthus spinosus $L$ ) terhadap Shigella flexneri dapat disimpulkan bahwa:

1. Infusa akar bayam duri (Amaranthus spinosus L) tidak memperlihatkan aktivitas antibakteri terhadap Shigella flexneri.

2. Konsentrasi Hambat Minimum(KHM) infusa akar bayam duri (Amaranthus spinosus $L$ ) terhadap Shigella flexneri sulit ditentukan karena larutan uji keruh.

3. Konsentrasi Bunuh Minimum (KBM) infusa akar bayam duri (Amaranthus spinosus L) pada konsentrasi 50\%, $25 \% ; 12,5 \% ; 6,25 \%$ dan $3,125 \%$ ter- 
hadap Shigella flexneri tidak dapat ditentukan karena pada semua perlakuan ditumbuhi bakteri.

\section{DAFTAR PUSTAKA}

Anonim. 1979. Farmakope Indonesia Edisi III. Jakarta: Departemen Kesehatan Republik Indonesia.

Anonim. 1985. Cara Pembuatan Simplisia. Jakarta: Departemen Kesehatan Republik Indonesia.

Anonim. 1986. Sediaan Galenika. Jakarta: Departemen Kesehatan Republik Indonesia.

Anonim. 1993. Dasar-Dasar Pemeriksaan Mikrobiologi. Yogyakarta: Bagian Mikrobiologi Fakultas Kedokteran UGM.

Anonim, 2001. Inventaris Tanaman Obat (1) Jilid 2 Bakti Husada Departemen Kesehatan Dan Kesejahteraan Sosial Republik Indonesia.

Anonim, 2003. Kurikulum 2004 SMA Pedoman Khusus Pengembangan Silabus dan Penilaian Mata Pelajaran Biologi. Direktorat Pendidikan Menengah Umum, Ditjen, Dikdasmen. Jakarta.
Anonim. 2006. Kurikulum Tingkat Satuan Pendidikan. Direktorat Pendidikan Menengah Umum, Ditjen, Dikdasmen. Jakarta.

Anonim. 20071. Amaranthus spinosus http:// www.realgreenlawns.com/ austin_tx_texas/weedidentification_ files/image005.pngVikipedi, özgür ansiklopedi. Download tanggal $12 \mathrm{Mei}$ 2007.

Anonim. $2007^{2}$. Amaranthus spinosus http:// cal.vet.upenn.edu/poison/plants/ slides/10501g.jpg. Download tanggal 12 Mei 2007.

Anonim. 2007³. Shigellaflexneri. http://upload.wikimedia.org/wikipedia/ Commons/thumb/2/29/Shigella_stool. jpg/260px-Shigella_stool.jpg .Download tanggal 12 Mei 2007.

Anonim. 20074. Pengembangan Bahan Ajar. http://www.google.co.id/searh?q= mo $\mathrm{dul}+$ pembelajaran $\& \mathrm{hl}=\mathrm{id} \& \operatorname{start}=0 \& \mathrm{~s}$ a.

Ansel, Howard, C. 1989. Pengantar Bentuk Sediaan Farmasi. Jakarta: UI Press.

Backer, CA dan RC.B Van den Brink. 1962. Flora of Java. Volume I Neterland. 
Breed, R, S, 1957. Bergey's Manual Of Determinative Bacteriology. The William and Wilkins Company.

Dwidjoseputro. 2005. Dasar-Dasar Mikrobiologi. Jakarta: Djambatan.

Feteriyani, R, 2004. Uji Aktivitas Antibakteri Infusa Akar Bayam Duri (Amaranthus spinosus. L) terhadap Staphylococcus aureus ATCC 25923 dan Escherichia coli ATCC 35218 serta Profil Kromatografi Lapis Tipis, Skripsi Universitas Ahmad Dahlan Yogyakarta.

Ganiswarna, dan Nafrialdi, 1995. Pharmakologi Dan Terapi. Edisi IV. Jakarta: Bagian Farmakologi Fakultas Kedokteran UI.

Hanafiah, Kemas Ali. 2005. Rancangan Percobaan Teori dan Aplikasi. Jakarta: PT Raja Grafindo Persada.

Harborne.J. B,1987. Metode Fitokimia Penuntun Cara Menganalisis Tumbuhan. Jakarta : EGC

Kuswandi, M, Susi Iravati, Rahayu, Ratna T. D, Ani Setyaningsih. 2000. Daya Antibakteri Minyak Atsiri Adas Manis (Foeniculum vulgare) Terhadap Bakteri Yang Resisten Antibiotik, Jurnal
Farmasi Indonesia, Pharmacon Pharmaceutical Journal of Indonesia, Vol no 2. Surakarta: Universitas Muhammadiyah Surakarta.

Jawetz. Melnick,dan Adelberrg. 2005. Mikrobiologi Kedokteran. Jakarta: Salemba Medika.

Mulyasa. 2004. Kurikulum Berbasis Kompetensi. Bandung: PT Remaja Rosadakarya.

Mulyasa. 2006. Kurikulum Tingkat Satuan Pendidikan (KTSP). Bandung: PT Remaja Rosadakarya.

Nasution S. 2000. Berbagai Pendekatan Dalam Proses Belajar Dan Mengajar. Jakarta: PT Bina Aksara.

Pelczar and Chand., 1988. Dasar-Dasar Mikrobiologi. Jakarta: Universitas Indonesia Press.

Robinson, Trevor. 1995. Kandungan Organik Tumbuhan Tinggi. Bandung: ITB

Sardjoko. 1989. Analisis Metabolit Sekunder. Yogyakarta: Pusat Antar Universitas Bioteknologi Universitas Gadjah Mada. 
Shulman. 1994. Dasar Biologi Dan Klinis Penyakit Infeksi. Yogyakarta: Gadjah Mada University Press.

Sudjoko. 2000. Pengajaran Biologi Berbasis Sekolah. Yogyakarta: FMIPA Universitas Negeri Yogyakarta.

Susilo, M. J. 2004. Pondasi Bagi Calon Guru Dalam Kegiatan Belajar Mengajar. Universitas Ahmad Dahlan Yogyakarta.

Sugiman. 1989. Petunjuk Laboratorium Isolasi Dan Identifikasi Mikroorganisme. Yogyakarta: Fakultas Kedokteran Hewan Universitas Gadjah Mada.

Supardi, Imam. 1999. Mikrobiologi Dan Pengolahan Dan Kemasan Pangan. Bandung: Penerbit Alumni.

Suryobroto, B. 1986. Mengenal Metode Pengajaran di Sekolah dan Pendekatan Baru dalam Proses Belajar Mengajar. Yogyakarta: Penerbit Amarta.

Syaefoellah, L, M. 1996. Ilmu Penyakit Dalam. Jakarta: FKUI.

Trease, E, G dan Evans, W, C. 1989. Pharmacognosy 13th. London: ELBS
Triadmojo, Pudjarwoto. 1996. Infeksi Bakteri Enteropatogen pada Balita Penderita Diare di Jawa Barat dan Pola Resistensinya terhadap Beberapa Antibiotik Jurnal Cermin Dunia Kedokteran Jakarta: Badan Penelitian dan Pengembangan Kesehatan Departemen Kesehatan RI.

Usman, Moh. Uzer. 2005. Menjadi Guru Profesional. Bandung: PT. Remaja Rosda Karya.

Voigth, R. 1995. Buku Pelajaran Teknologi Farmasi. Yogyakarta: UGM Press.

Volk dan Wheeler,1990. Mikrobiologi Dasar jilid 2 edisi kelima. Jakarta: Erlangga.

Wijayakusuma. H.M.H., 1994. Tanaman Obat Berkhasiat Di Indonesia jilid 1. Jakarta: Pustaka Kartini.

Winarno, Hendik. 1995. Lipid A- Pusat Aktif Endotoksin, Struktur Kimia dan Bioktivita Jurnal Cermin Dunia Kedokteran. Jakarta: Pusat Aplikasi Isotop dan Radiasi-BATAN. 